A-1-9:00

\title{
パルス型 Nd:YAGレーザ照射の歯石除効果
}

松本歯科大学歯周治療学詇座

○佐藤 哲夫、日坦 孝一、椎名 直樹、温 慶雄、伊藤 茂樹、音琴 淳一、太田 紀雄

The Effect of Nd:YAG Laser Irradiation for Calculus Removal

Department of Periodontology, Matsumoto Dental University

$\bigcirc$ Tetsuo Sato, Koichi Higaki, Naoki Shiina, Ching-Shiong Wen, Shigeki Ito, Jun-ichi Otogoto

and Norio Ota

キーワード : パルス型 Nd:YAG レーザ、歯石除去

【目的】

パルス型 Nd:YAG レーザ照射器のうち、レーザファイバー先端の直径が細く、エアーおよびスプレー洗浄

が可能で、その先端の加工によりレーザ光の拡散が可能な機種における菌石除去効果を検討した。

【材料および方法】

1) 材 料

照射器として、パルス型 Nd:YAG レーザとしてパワーパルス 1 （エス・エル・ティ・ジャパン社製、

東京）を用いた。送気送水可能なハンドピース、ファイバ一直径は $400 \mu \mathrm{m}$ 用いた。照射条件は $100 、 400 \mathrm{mj} 、$ $900 \mathrm{mj} 、 1$ 10pps とした。またファイバー先端（ベア部）は通常の照射と特殊先端加工器（加工ポット） による光拡散処理した後、照射を行った。

便宜拔㐘した抜去歯からエナメル質、セメント質、象牙質片を採取し被照射面として用いた。歯周疾患 罹患拔去歯におけるエナメル質、セメント簤に歯石が付着した面を被照射面とした。

2) 方 法

（1）照射条件による困貎表面の温度変化

歯面上あるいは歯石上の温度変化をスターリングクーラ型コンパクトサーモ（日本アビオニクス（株）、 東京）を用いて計測した。照射は各菌面でぞれぞれ 7 回行い、最大最少を除いた平均值を算出した。

（2）照射条件による歯面の変化

各歯面照射後、表面形状の変化は surfcom180A（東京精密社製、東京）にて表面形状の変化を測定し た。さらに表面観察は走査型電子顕微鏡（SEM : JCXA733、日本電子、東京）にて表面観察を行った。

（3）照射条件による歯石除去効果の比校

歯石付着表面に対して、超音波スケーラー、手用キュレット型スケーラーのスケーリング面との比較 を行った。測定、観察条件は上記と同様に行った。

【結 果】

1）照射条件による菌質表面の温度変化

レーザーを歯面、歯石付着部位に照射した温度と比較して、エアガン、送水機構付ファイバーハンドピ 一スを用いた照射による表面温度は $25^{\circ} \mathrm{C}$ 以下となり有意に低下した。

2）照射条件による歯質表面の変化

標準ファイバーによる照射により、歯面ならびに歯石表面の表面形状の変化が認められた。象牙質面に おいては照射条件によってはスミア層の除去が観察された。

3）照射采件による歯石除去効果の比校

900mj においでは対象面への垂直照射により菌石除去効果を認めた。標準照射と比較して加エファイバ

一による処理後の水平照射により歯石除去効果を想めた。

\section{【考 察】}

先端がフレキシブルな細いファイバー先端を持つ本機種において、ノンコンタクトで、かつ色素にてマー キングしない形での臨床応用を検討するための基礎的実験を行った。結果により、エアガンと送水によるス プレーにより歯肉縁上、縁下に関わらず臨床応用が可能であることが確認された。肉眼で確認され得る大き な歯石の除去に対しては㭙間的な配虑からも適当でなく、コンタクトがない状態でも加工ポットにより照射 による歯石除去が可能であるため、複雑な歯根形態における歯石除去に応用できると推察できる。

\section{【結 䄖】}

本機種により歯面の状態に関わらず、エアーおよびスプレー照射によりレーザー光による被照射面の表面 温度が上昇せずに照射が可能であった。さらに加エファイバーにより、菌石除去効果が上昇した。しかし、 非接触型超音波スケーラーのように大量の歯石除去には向いていないことが確認された。 


\section{ルートプレーニングか病的歯の移動に及ぼす影響 九州歯科大学歯科保存学第 2 講座}

○村岡宏祐、佐野文美、中村太志 吉見浩、田代芳之、久保田浩三横田誠 Effect of root planing on pathologic tooth migration of experimental periodontitis

Department of Periodontology and Endodontology, Kyushu Dental College

OKosuke Muraoka, Fumi Sano, Taiji Nakamura, Hiroshi Yoshimi, Yoshiyuki Tashiro,

Kohzoh Kubota and Makoto Yokota

キーワード : 実験的歯周炎, 病的歯の移動, ルートプレーニング

【目的】

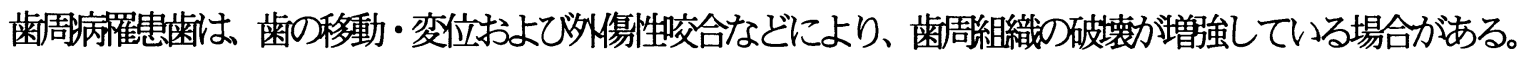

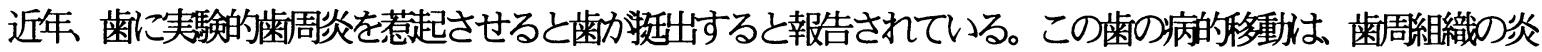

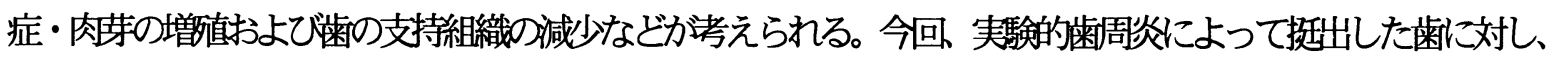
ルートプレーニングか值直的な歯の変位にどのように影響するかを検扵した。

【材料および方法]

実験動物はさ、健康な体重9〜12kg の雄の3歳のビーグル成犬8頭を用いた。

炎症群 (Group1) は、4頭の下鶜左側P3を用いた。消炎群（Group2）は 4頭の下頢左側P3を用いた。 健康群（Group3）は8 頭の下䫑右側P3 とした。

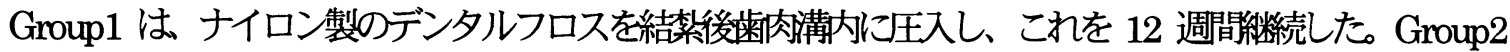

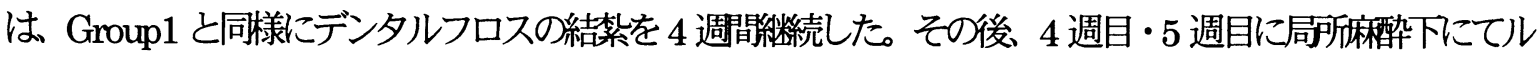
ートプレーニングを行った。さら 週3回のTooth cleaning を12 週目まて続けた。Group3は，週3回の Tooth cleaning 12 週盟維持した。臨木パラメーターは 0 週から 1 週間おきにPPD・PAL・動新度および

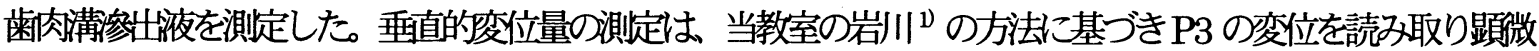
鏡で則定した

Group2 に関しては，0〜4週 (炎症苍起期、5〜7週（SRP期、8〜12週 (メインテナンス期)の3つの 時期に分類し、分析を行つた。

[結果および考察]

Group1 は，夷駼終了まで歯の括出を続けた。Group2 は、炎症苍起期において、Group1 之同程度の歯の 挺出を認めた SRP期ては ルートプレーニンク目後、さらなる歯の挺出を認姉た。メインテナンス期では。 健康な歯周組織に改善するとともにGroup1 と比へ擞出量の有意な低下を認めた。なお、Group3は，実験期 間中わずかではあるが挻出を認めた。

今回 実験的㐘周炎歯において、ルートプレーニングにより挺出量の有意な低下を認めた。これは、消炎に

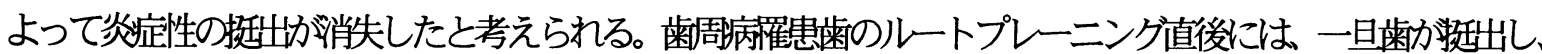
その後拖出量の低下を起こすことが分かった。ルートプレーニング直後の歯の挺出は反応性の炎症によること カ䊒則される。

1）岩川忠:日歯周誌，37:1-10，1995 


$$
\text { ペリオプレーニングバーの試作（1） }
$$

明海大学歯学部歯科臨床研究所

○溝部健一, 元村洋一, 大音孝一, 松田 哲, 山浦修治, 好士哲雄, 奈良文雄, 荒木久生

Trial products of Perioplaning Bur (1)

Post-Doctoral Institute of Clinical Dentistry, Meikai University School of Dentistry

OKenichi Mizobe, Youichi Motomura, ,Takaichi Ohto, Satoru Matsuda, Syuuji Yamaura,Tetsuo Koushi, Fumio Nara, and Hisao Araki

キーワード : ルートプレーニング、ルートプレーニングバー、歯周外科、回転切削器具

【目的】

ルートプレーニングの効率化および手用器具が到達困難な部位での使用を目的として、回転切削器具が 臨床に応用されている。ところが現在日本で発売されている回転切削器具は、器具の大きさや先端形状、 そして、ダイヤモンド粒度などの点で使用しにくいことが多く、手用器具の方が一般に広く用いられて いる。しかしながら、効率化を考慮すると、回転切削器具は、臨床的にたいへん有効である。そこで今 回、上記 3 項目を改善したルートプレーニングバーを開発し臨床応用しているので、その第 1 報として、 バーの形状や特徵を中心に報告する。

【材料および方法】

1.ペリオプレーニングバー

バーは、エンジン用であり最高回転数を2,000rpmとした。

1)先端形状

フットボール型（ISO 014、ダイヤ長 $5.1 \mathrm{~mm}$ 、最大径 $1.4 \mathrm{~mm}$ 、全長 $27.0 \mathrm{~mm}$ ） とラウンドエンドテーパ 一型（ISO 012、ダイヤ長 $7.1 \mathrm{~mm}$ 、先端径 $0.6 \mathrm{~mm}$ 、最大径 $1.2 \mathrm{~mm}$ 、角度 5.5 度、全長 $28.5 \mathrm{~mm}$ ）の2種類を 作製した。

2)ダイヤモンド粒度

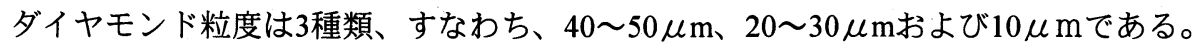

2. バーによる切削状態の比較

ダイヤモンド粒度の差による切削状態の検討を行うために、抜去歯を用いて定圧、定回転での切削を 行い、顕微鏡下で観察した。

【結果】

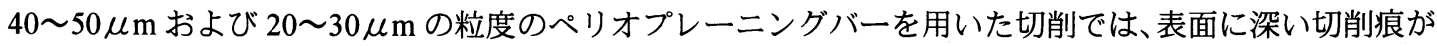
認められた。一方、10 10 mのペリオプレーニングバーを用いた切削では、深い切削痕は認められなかっ た。

\section{【考察】}

プレーニングバーを用いたルートプレーニングでは、回転切削器具の特徵でもある深い切削痕が認められ ることが多い。この切削痕は、短に表面が凹凸となるだけではなく、歯石やプラークの付着を物理的に助

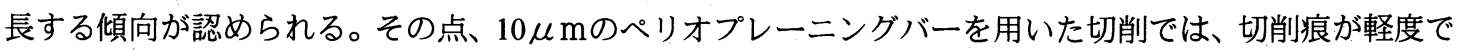
あり、臨床に十分利用できるものと考える。

【まとめ】

新たに開発したペリオプレーニングバーの有効性が、確認できた。 
自発的骨再生療法ＯＢＥＴの骨再生メカニズムについて

$$
-(1)-
$$

深田口腔顎難治疾患研究所

○梁田邦雄 佐々木誠 吉川正美 服部久道 檜山隆一

The mechanism of bone regeneration on spontaneous bone regeneration Therapy $0 \mathrm{BET}$

- (1) -

Fukada Research Institute of Intractable Stomatomaxillary Affection

OKunio Fukada, Makoto Sasaki, Masami Yosikawa,

Hisamichi Hattori, Ryuichi Hiyama

キーワード : 非外科療法、骨再生療法、骨芽細胞の力学的変形と骨の再生

目的

現在、歯周病によって惹起された骨欠損の骨を再生させるには G T R 法、エムドゲイン法などの

外科的骨再生法に頼らずを得ないというのが歯周病学の一般的通説である。

演者深田は「骨芽細胞の力学的変形が細胞膜の透過性を増し、C Aイオンの増加などC A 代謝に重大 な影響を与える」という、「骨と電気刺激の研究」の成果をもとに、自発的骨再生療法 O B E T 提唱し

てきた。しかし、この研究成果だけでは垂直骨欠損の骨再生人カニズムを説明するには不充分であった。

そこで、この非外科的骨再生療法によって、得られた骨再生例を厳密に調査した結果、重大な事実

を発見した。多くの非外科的骨再生例の場合、垂直骨欠損が大きい側から反対側に歯牙は自発的に移動 しながら骨の再生は起きていた。すなわち、本来、健康な歯根膜線維には弾力性があり、その付着の多

い側に歯牙が旁引されて、移動現象は起きたと推測された。また、これらは歯根膜線維の付着量の差に よって起きる歯牙の移動力は骨欠損の大きい側の歯根膜線維に反対側より大きな負荷を与えるのではな いかと考えた。そこで、歯根膜線維の付着量の差それ自体が垂直骨欠損が大きい側（歯根膜線維の付着 量の少ない側）に負荷が発生させるかをin vitroで確かめることをにした。

材料㧍上び方法

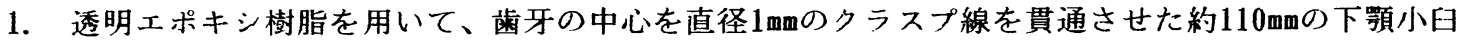
歯の模型を作製、クラスプ線は模型内を可動できるようにした。それをワックスで固定した。

2. 同じく透明エポキシ樹脂を用いて、歯槽窝を作製、根尖相当部にクラスプ線が収まる深さの穴を 形成しておいた。歯槽富の歯槽骨頂は骨縁下ポケットを想定して、近心が低く、遠心は高く作製した。

3. クラスプ線を調整して歯牙模型が歯槽骨力内で浮いた状態にした。さらに解剖学的な歯根膜線維 の付着状態を想定し、歯槽容、歯根面に矯正用スライディングフックを接着した。

4. 貫通しているクラスプ線を活用しながら、矯正用のゴムを該当するフックに装着する 結果

1. 固定してあるクラスプ線を緩めると、矯正用のゴムが多く装着されている側に歯牙は傾斜した。

2. 矯正用のゴムが少ない側はゴムが伸びて、負荷が係っていることが明らかだった。

考察

1. 臨床的には適切な S R P および歯周ポケット内のプラークコントロールによって茵根膜線維の弾 性は回復するものと考えられる。

2.このように、健康な歯根膜線維の存在下では、実験結果からも明らかなように、垂直欠損が大きい 側の柬根膜線維には反対側より大きい負荷がかかる。そしてこれは㐘根膜線維の付着量の差によっても たらされたものであることも意味している。

3. 歯根膜線維に発生した負荷は歯根膜線維に連結している骨芽細胞に力学的変形を与え、C Aイオ ンの増加など C A 代謝に影響を与え、自発的に骨再生が起きたと考えられる。さらに自発的な骨の再生 は垂直骨欠損が大きい側から反対側に歯牙が自発的に移動しながら発生すると考えられる。 結論

1. 自発的な骨の再生には適度な㐘根膜線維の付着量の差が不可欠である。

2. 非外科的に自発的な骨の再生を期待するのであれば、垂直骨欠損が大きい側から反対側に歯牙が 自発的に移動しながら骨再生が起きる可能性を念頭に置き、対処しなければならない。

3. 具体的には近遠心の移動を妨げている補緅物の撤去、暫間固定の適切な調整が必要である。

4. 自発的歯牙の移動が起きる前の補綴物の装着は避けるべきである。 
自発的骨再生療法ＯＢＥＴの骨再生メカニズムについて

$$
\text { - ( } 2 \text { ) - }
$$

樑田口腔影難治疾患研究所

梁田邦雄 佐々木誠 吉川正美 ○服部久道 檜山隆一

The mechanism of bone regeneration on spontaneous bone regeneration therapy $\mathrm{OBET}$

$$
-(2)-
$$

Fukada Research Institute of Intractable Stomatomaxillary Affection

Kunio Fukada, Makoto Sasaki, Masami Yosikawa,

OHisamichi Hattori, Ryuichi Hiyama

キーワード：非外科療法、骨再生療法、歯牙の移動と骨の再生

目的

自発的骨再生療法 O B E T の骨再生メカニズムの知見および採用上の注意点を順守し、意図的に、非外 科的かつ自発的な骨再生を臨床上で試みた。

材料および方法

1. 近心又は遠心に $6 \mathrm{~mm}$ 以上のプロービングデプスが存在し、X線上でも、明らかにインフラボニー

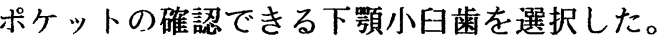

2. 蕨密な S R P のあと、移動が予測される側にスペースの余裕がなく、移動の障害になる症例には歯 冠修復物の撤去を行った。

3. 咬合性外傷が解消されるように上下顎のクリアランスはそれぞわ十分確保した。

4. ブラッシング法はポケット内のプラークコントロールが効果的に行える1列歯ブラシを用い、1日 5 回以上の多回法を採用した。

5. 歯内㞠法はカルシウム製剂を併用したRET法を採用した。

6. 㐘周外科は行っていない。

結果

1. 約6力月から12力月の間に歯牙は骨欠損の少ない側に自発的に移動し、垂直骨欠損の部位には $3 \mathrm{~mm}$ 以上の骨の再生が観察できた。

2. 自覚症状も著しく改善した。 考察

1.「自発的骨の再生は自発的に歯牙の移動とともに起きる」というO B E T の骨再生理論の信憑性 がさらに高まった。

2. S R P の精度やブラッシング法の内容によってその成功率に影響がでることは否めない。 結論

1. 垂值的骨欠損部に、意図的に自発的骨再生が可能になったことの意義は極めて大きい。

2. 単根などの S R P が確実に行える罹患歯の治瘠率がさらに高まる。

3. 自発的骨再生理論は現在の歯周補緅の考え方に重大な見直しが必要であることを示唆している。

4. 治療用義歯や暫間固定の調整・取り扱いに発想の転換が必要となる。

5. 自発的骨再生療法 O B E T の骨再生理論の応用は一般的歯周外科のみならず、G T R 法、エムド ゲイン法などの外科的骨再生療法の予後をさらに良好な結果に導くためにも有効であると考えられる。

6. 㐘周病治療のメインテナンスの概念の本格的見直しを必要亡する。

7. 骨整形を行い、歯根膜線維の付着量の差を消㙎させることは必然的に骨の自発的再生を停止させ ることになる。 
$A-6-10: 00$

重度歯周炎罹患歯列に対する歯の自家移植の有用性

- 移植前・後における骨内歯根表面積の検討 -

永田むつみ歯科医院

永田睦

Efficacy of autogenous tooth transplantation for the preservation of severe periodontitis-affected dental archs.

- Measurement and comparison of the intrabony root surface between pre and post treatment periods-

Nagata Dental Clinic

Mutsumi Nagata

キーワード : 重度歯周炎、歯の自家移植、骨内歯根表面積

[目的]

歯周炎罹患歯列におけるクロスアーチスプリンティング(CAS)の有効性は、多くの研究により立証され ている。しかし臨床の場においては、かならずしも理想的な位置に歯が残存しているとは限らず、そのよ うな状況で CAS が選択された場合、その予後はかなり懐疑的なものと考えられる。

今回は、残存歯の咬合支持の増強と適正な支持域の再配分のため、歯の自家移植を行い、最終的にCAS によって咬合再構成を行った䨑周炎症例を、歯根表面積という観点から検討を行った。

[材料と方法]

〈対象＞ 中等度加重度の歯周炎で、歯列の保存を目的として、上䪽歯周外科時に崡の自家移植（再植 を含む）を行い、最終的にCASによって咬合を再構成した患者 20名（男性4名、女性 16名）について 検討を行った。対象患者の年齢は 39歳 - 75 墄、平均 54.8歳であった。これらの症例において、デンタ ルX線写真より、術前と術後における雪根の骨内相当部推定表面積\%を算出し、初期治療開始時とCAS 装 着後の 2 群間で比較した。また probing depth (PD) 、動摇度なども計測した。PD は Hu-Friedy 社 probe を用い、6 点法で計測した。動摇度の測定は、Gulden 社製ペリオテストを使用した。

〈骨内崡根表面積の算出法> 1) 阪神社製インジケーターを用い二等分線法で撮影したX線像上で、近 心・遠心における䨑根長に対する骨内相当部歯根長の比を求め平均した。2）算出された值を、日本人の 歯根表面積標準値をもとに作製した換算式に当てはめ、相当雪根表面積\%を算出した。3）得られた\% 値 から、日本人の平均表面積の值を基準として、それぞれの歯の骨内歯根推定表面積を算出した。4) 残存 雪の骨内雪根表面積を合計し、さらにその值を標準値の合計面積で除し、全歯根表面積に対する骨内歯根 表面積の総\%を推算した。5) 術前・術後値の算出にあたっては、それぞれの歯において、アタッチメン トレベルに変化がないものと仮定して術前の值を術後にも応用して算出した。また分割崡根では、下顎近・

這心根、上䪽口蓋根で当該歯の推算値の $1 / 2$ の値を使用した。

[結果]

移植雪は38本で、移植後、最終補緅物（CAS）装着までの期間は 2 力月から 20 力月、平均 7.0 力月で あった。PD、ペリオテスト值ともに、治療前・後で有意に減少した $(P<0.001)$ 。初期治療開始時の残 存歯根表面積は $30.54 \pm 23.54 \%$ 、最終補緅物装着後では $32.13 \pm 23.69 \%$ \%り、両群間に有意差は 認められなかった。最終補緅物装着後の歯根表面積の最小のものは、9.67\%であった。

[ 考察および結論]

雪周炎が進行した症例で、かつ残存䨑がアンバランスな配置となっている場合、歯周焱罹患歯列の治療 と保存は困難な場合が多い。本結果からは、通常では咬合を維持するのに困難と考えられるような小さい 骨内歯根表面積でも、咬合機能と形態が維持されていることが示された。咬合支持の堌強と適正な支持域 の再配分に有効な歯の自家移植とCAS の組み合わせによって、こうした重度の歯周炎罹患雪列のさらな る保存・延命の可能性が示唆された。 


\section{Supportive Periodontal Treatment の効果を左右する因子に関する研究}

\section{岡山大学大学院医歯学総合研究科歯周病態学分野}

$\bigcirc$ 杉典子, 清水明美, 山崎太士, 岡本慎治, 矢野亜紀, 前田武将, 工藤値英子, 松浦香織,

山口万有美, 大森一弘, 明貝文夫, 千原敏裕, 中川政嗣, 新井英雄, 西村英紀, 高柴正悟, 村山洋二

A Study on Factors Influencing Effect of Supportive Periodontal Treatment

Department of Periodontal Science, Okayama University Graduate School of Medicine and Dentistry

ONoriko Sugi, Akemi Shimizu, Taishi Yamasaki, Shinji Okamoto, Aki Yano, Takemasa Maeda, Chieko Kudo, Kaori Matsuura, Mayumi Yamaguchi, Kazuhiro Omori, Fumio Myokai, Toshihiro Chihara, Masatsugu Nakagawa, Hideo Arai, Fusanori Nishimura, Shogo Takashiba, Yoji Murayama

Key word：Supportive Periodontal Treatment，急性発作，根面う蝕

\section{【目的】}

Supportive Periodontal Treatment（SPT）は必ずしも健全な歯周組織を回復した患者にのみ適 応させるものではない。したがって, SPT 患者が持つ個人個人のリスク毎に SPT の内容を変 える必要がある。本研究は, 個々の患者に対して効果的な SPT を行う基準を構築するために, SPT 期間中に起こつた臨床症状の実態を調べ，臨床検査項目との相関から，SPT の効果を左 右する因子を考察するものである。

\section{【材料と方法】}

被験者とその分類: 被験者は, 岡山大学歯学部附属病院第二保存科において初期治療および 一連の観血処置を受けた後, 約 24 ケ月以上継続して管理下にある患者を SPT 患者とした。SPT 移行時の歯周状態に基づいて SPT 患者を次の 3 群，すなわち治療後 SPT 群 ; 歯周治療後に健 康な歯周組織の状態を回復した群, 試行的 SPT 群; 観血的な歯周治療後であっても歯周炎病 変を残している群, そして妥協的 SPT 群 ; 何らかの理由で観血的な歯周治療を行うことがで きなかった群に分類した。

侮床検査：SPT 期に起こった臨床症状の悪化は，急性発作，歯周ポケット長深化，および根 面う蝕の発症の, 有無から検查した。臨床検查項目は, 歯周ポケットからの口腔内細菌 $(A$. actinomycetemcomitans, P. intermedia, P. gingivalis) と歯肉縁上プラークからのA. viscosus の 検出, 唾液の口腔内細菌 (S. mutans, Lactobacillus sp.) 数, $A a, P i, P g$ に対する血清 $\mathrm{IgG}$ 抗体 価, 唾液量, 唾液緩衝能, 喠液粘稠度, 飲食回数, フッ素入り歯磨剂の使用状況, O'Leary の plaque control record，露出根面割合，修復根面割合とし，それぞれに指数を設けた。

統計 : 統計処理は, $\chi 2$-検定と Mann-Whitney 検定を用いた。

\section{【結果】}

1. 臨床症状の悪化は, 治療後 SPT 群では, すべての検査項目において低く, 試行的 SPT 群 では歯周ポケット長深化とう蝕の発症率において高く, そして, 妥協的 SPT 群ではう蝕 の発症率において高かつた。

2. 試行的 SPT 群と妥協的 SPT 群は，治療後 SPT 群よりう蝕の発症率が有意に高かった。な お，治療後，試行的，および妥協的 SPT 群それぞれの群間において，急性発作とポケッ 卜長深化の発症率に有意な差はなかった。

3. 各 SPT 群間で有意な指数差を示す臨床検査項目は, フッ素入り歯磨剤の使用の有無のみ であった。すなわち, 治療後 SPT 患者群は, 試行的 SPT 患者群より同歯磨剤の使用頻度 が高かった。

\section{【考察と結論】}

SPT 移行時の歯周状態によって，SPT 期間中に発現する臨床症状には違いがあることがわ かうた。とりわけ, 試行的 SPT と妥協的 SPT 患者は, 治療後 SPT 患者よりう蝕を発症しや すいことがわかった。また，う蝕発症は SPT 期の大きな問題であることがわかった。臨床検 査項目のうち, 統計学的には明確な SPT の効果を左右する因子として検出し得なかったもの においても, 検査方法を吟味することによって SPT 群間の違いを指摘できそうなものがあっ た。今後, この種のデー夕分析を重ね, 患者に適した SPT 対応法を確立したいと考える。 
A $-8-10: 30$

\author{
大阪大学歯学部附属病院歯周病診療室における診療実績とその効果 \\ 大阪大学 大学院歯学研究科 口腔分子免疫制御学講座 (口腔治療学) \\ ○松尾理絵 北村正博 山下元三 寺倉まみ 山田 聡 小鄉秀司 高山真一 佐保輝之 \\ 野崎岡徳 平野裕之 島袋善夫 村上伸也 岡田 宏 \\ The Longitudinal Eefects of Periodontal Treatment at 0saka University Dental Hospital \\ Department of Periodontology ,Osaka University Graduate School of Dentistry \\ ORie Matsuo, Masahiro Kitamura, Motozo Yamashita, Mami Terakura, Satoru Yamada, Hideji Ogo \\ Shin-ichi Takayama, Teruyuki Saho, Takenori Nozaki, Hiroyuki Hirano, Yoshio Simabukuro, \\ Shinya Murakami and Hiroshi Okada
}

〔キーワード〕歯周治療 治療効果 メインテナンス

[目的]

大阪大学雪学部附属病院歯周病診療室では、昭和 54 年より Goldmann らによって提唱された、診査診 断、初期治療、再評価、歯周外科処置、メインテナンスと続く歯周病の病因論に基づく治療体系のもと、 歯周病の計画治療を行ってきた。今回、本院歯周病診療室における歯周治療の診療実績とその効果の検 討を行った。

〔材料および方法〕

大阪大学歯学部附属病院歯周病診療室で、昭和 54 年 (1979) 以降平成 12 年末 (2000) までに計画治 療を行った 2211 人の歯周炎患者を被験者とし、男女比率、年龄構成、年度別来院者数、年度別現在来 院者数、年度別現在来院率および各患者のメインテナンス期間について調べた。また、10 年以上メイン テナンスしている患者を対象として、初診時、再評価時、メインテナンス開始時および平成 12 年末現 在の残存歯数を調へ、その経時的な変化より、計画的歯周治療の有効性について検討した。

[結果および考察]

昭和 54 年以降平成 12 年末までの年度別来院者数は、平成 6 年までは一年間に約 100 人程度であった が、それ以降徐々に増加し平成 11 および 12 年度には $180 \sim 190$ 人程度で、昭和 54 年以降平成 12 年末 までに延べ 2211 人（男性 894 人、女性 1317 人、男女比約 4 対 6) の歯周病患者の計画治療を行った。 この 2211 人のうち、平成 12 年末現在、735 人が治療を継続しており、その初診年別の現在来院者数と その人数のその年に計画治療を開始した全患者に対する割合（現在来院率）については、来院歴の長い 患者ほど現在の来院率が低下する傾向が見られた。そして、本院歯周病診療室において初診から約 10 年が経過した患者で現在でも継続して Supportive periodontal therapy（SPT）を受けている患者は全体の約 $1 / 3$ であった。また、10 年以上 (平均 13.1 年) SPT を行っている患者 97 人を抽出し、初診時（平均 46.9 歳)、再評価時 (平均 47.4 歳)、SPT 開始時 (平均 49.1 歳) と平成 12 年 12 月 31 日現在 (平均 62.2 歳) の残存歯数を比較した。その結果、被験者 97 人の初診時の平均残存歯数は 26.1 本、再評価時には 25.4 本、SPT 開始時には 23.9 本で、平均 13.1 年間の SPT を行った平成 12 年 12 月末現在では平均 21.3 本 であった。すなわち、初診から再評価、メインテナンス開始までの平均 2.2 年間に 2.2 本の歯を喪失し たのに対し、平均 13 年間のメインテナンス期間には、2.6 本しか歯を唯失しなかった。この結果は、平 成 11 年歯科疾患実態調查で明らかとなった年齢別の日本人の平均残存歯数と比較し、本院歯周病診療 室において 10 年以上 SPT を受けている患者が、SPT 期間に喪失する歯数が一般の人に比べて著しく少 なく、本診療室における SPT が㐘の保存に非常に効果的に働いていることを示唆していると考えられる。 
インプラント周囲炎におけるインプラント体の垂直的荷重に対する変位動態 九州歯科大学歯科保存学第 2 講座 • 九州歯科大学物理学教室*

○田隅志保、元島ふくみ、内藤 徹、日高理智、*田中眞理子、横田 誠

The measurement of implant displacement under vertical loading on peri-implantitis

Department of Periodontology and Endodontology, Department of Physics*,Kyushu Dental College

OShiho Tazumi, Fukumi motoshima, Toru Naito, Masatoshi Hitaka, * Mariko Tanaka and Makoto Yokota

キーワード : peri-implantitis, vertical loading, implant displacement

【目的】

インプラント治療が普及するにつれて、その長期的な予後観察が重要視されてきているが、 実際にはインプラントの機能評価の適切な方法はなく、その研究も十分になされていない。我々 の教室では、従来、病的な歯の機能的動態についての研究を行ってきており、その結果天然歯 においては、炎症の存在により垂直的荷重に対する変位動態が大きく変化することが明らかと なった。今回、周囲組織の健康なインプラントと、周囲組織に実験的に炎症を起こしたインプ ラントの、バイオメカニカルな評価をするために、垂直的荷重による経時的変位を測定した。

\section{【方法】}

体重 8〜12kg のビーグル成犬 6 頭を用いた。右側下顎 P1〜P4 を抜歯し、12 週の治瘉期間をお いた後、スクリュータイプチタンインプラントを埋入した。オッセオインテグレーションを獲 得した後、静脈内麻酔下で頭部を測定台に固定し、変位測定は、分解能 $1 \mu \mathrm{m}$ の高精度レーザー 変位計を用いて $10 \mathrm{~g} \sim 500 \mathrm{~g}$ まで荷重を垂直的に負荷して行った。計測間隔は 0.01 秒、荷重負荷 時間は 10 秒、荷重除去後の回復時間は 3 分に設定し前荷重の影響が残存しないよう配慮した。 測定は、ベースラインと、デンタルフロス結紮による炎症惹起後 1-6 カ月の 1 力月毎に行い、 同時に、歯周病学的臨床パラメータ（PPD、PAL、ペリオトロン值、ペリオテスト值）の測定と $\mathrm{X}$ 線撮影を行った。得られたデータは $\mathrm{AD}$ 変換後、パーソナルコンピュータにて分析を行った。

\section{【結果】}

1. 天然歯と同様にインプラントにおいても垂直的荷重 に対する変位を起こすことが確認されたが、その変 位量はわずかであった。

$2.30 \%$ 程度の骨吸収が認められ、著明な臨床パラメー 夕の変化の見られた炎症惹起後においても、変位量 の著しい増加は認められなかった。

3. 天然歯ではフォークトモデルに代表される指数関数 的な変位様式を示すが、インプラントは異なった様 式を呈した。

4. 他の臨床パラメータと比較して、ペリオテスト值の み有意な変化を示さなかった。

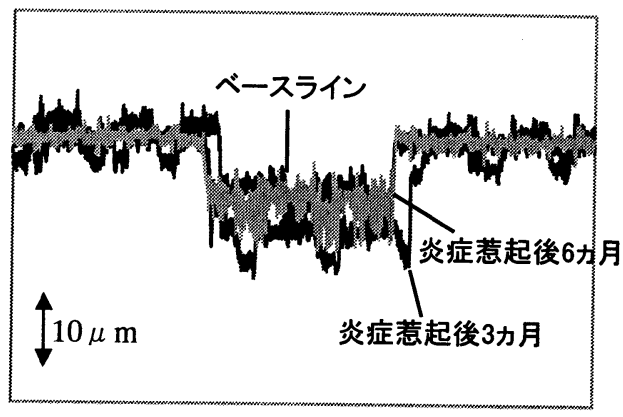

$100 \mathrm{~g}$ 負荷時の経時的変位

\section{【考察】}

インプラントにおいては、実験的周囲炎惹起後も、垂直荷重に対する変位とペリオテスト值 ともに変化が見られず、周囲組織に炎症が存在してもバイオメカニカルな影響が現れにくいこ とが示唆された。そのため、インプラントの機能評価を行うには、動摇度以外に $\mathrm{X}$ 線所見、プ ロービングなど種々の診査を併用し、細心の注意を払う必要があると思われる。 
A $-10-10: 50$

実験的インプラント周囲炎に対する治療方法の検討

明海大学歯学部歯周病学講座

○辰巳順一，小林之直, 大音孝一，細田幸子，山村加奈子，平瀬嘉雄, 東 高史, 申 基吉, 宮田 隆

The study of therapy for experimental peri-implantitis in monkeys

Department of Periodontology, Meikai University School of Dentistry

Junichi Tatsumi, Yukinao Kobayashi, Takaichi Ohoto, Sachiko Hosoda, Kanako Yamamura, Yoshio Hirase, Takashi Azuma, Kitetsu Shin, and Takashi Miyata

キーワード:インプラント周囲炎, 骨再生誘導法, 病理組織学的検討

【目的】

インプラント周囲炎によって破捿されたインプラント周囲組織は, 感染のコントロールや咬合の管理を行っても, 天然 歯のような治樜機転が働かないことを, 我々はこれまでの研究で示唆してきた. 今回の実験では, インプラント周囲资 によって破壊されたインプラント周囲組織に対し，より積極的な再生療法(GBR 法, 人工骨移植)を行い，インプラント体 表面の骨再生, およびインプラント体表面とのインテグレーション状態を病理組織学的に検討した.

【材料と方法】

全身的に健康な推定年齢 4 5 歲，体重 3.8 5.7kg のオス，カニクイザル(Macaca fascicularis) 6 頭の下顥両側第 2 小臼㐘および第 1 大臼歯部 12 部位を被験部位とし，同歯を抜歯した. 抜歯3力月後，全層弁を剥離しテーパード・ス

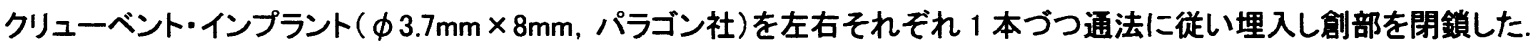
3 カ月の骨接合期間ののち, インプラント体の近遠心部に 3 壁性骨欠損を作製した(近遠心的幅経 $2 \mathrm{~mm}$, 頪舌的幅径 $2 \mathrm{~mm}$, 深さ $2 \mathrm{~mm}$ および $6 \mathrm{~mm})$. さらに, インプラント周囲にリガッチャーワイヤーを巻きつけ, 4 䢙間プラークコントロー ルを行わず, 実験的インプラント周囲炎を作製した. 再生療法を行う際には, 感染部位をエアフロー(クイックジェット) で感染源を除去した後，十分な生理食塩水で洗浄し，全層弁剥離のみ群(C 群), 吸収性 GTR 膜(Resorut, Gore-Tex 社)を用いた GBR 群(G 群)，自家骨移植を併用し，吸収性 GTR 谟を用いた GBR 群(A+G 群)，ボーンジェクト(高研) 移植群(B 群)を設定しそれぞれ処置した. 3カ月後に屠殺，組織切片を作製し，病理組織学的に覞察した.

【結果】

肉眼的所見では. インプラント周囲に炎症所見は認められなかったものの, B 群では, すべてのモデルで，術後 1 週

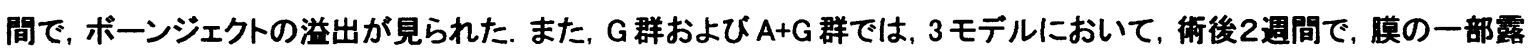
出が諰められた. それらのモデルに対しては，週に1度塩化ベンゼトニウム溶液で消毒を行った. レントゲン所見では， B 群においては，C 群と同様，著明な骨添加像は認められなかった.一方，G 群および A+G 群では，膜か露出したモ デル以外のモデルでは, 骨の添加が琶められた. 病理組織学的観察では, G 群および A+G 群では, 骨の添加が見ら れるものの，インプラント体との再骨接合は見られなかった. 
糖疗病教育入院患者の雪周病䍜患状態と生活環境との関連

北海道大学大学院歯学研究科口腔健康科学講座歯周病学分野

○岩坂 憲助、根岸 淳、寺田 裕、松橋 千佳子、小神 絵里子、

本郷 哲也、川浪 雅光

The Association of Periodontal Status of Diabetics with Manners of Their Lives

Periodontology and Endodontology, Department of Oral Health Science, Hokkaido University

Graduate School of Dental Medicine

OKensuke IWASAKA, Jun NEGISHI, Yutaka TERADA, Chikako MATSUHASHI,

Eriko OGAMI, Tetsunari HONGO and Masamitsu KAWANAMI

キーワード：糖尿病、歯周病、多变量解析

[目的]

糖尿病と歯周病の関連についてはこれまで世界中で数多くの報告がなされている。我々は多変 量解析を用いて糖尿病患者の病状と口腔内診査のデー夕を解析し、糖尿病に関するデー夕全体と Probing Depth および歯槽骨吸収に関連が認められたことを本学会第40 回秋季学術大会および第43 回 春季学術大会で報告した。糖尿病の罹患状態はライフスタイル等とも密接に関連しているが、糖尿 病患者の歯周病の状態とこれらとの関連についての報告は少ない。本研究では、糖尿病患者の歯 周病罹患状態と生活状態の関連性を検索するため、糖尿病患者における歯周診査デー夕と糖尿病 関連データおよび患者の生活データをロジスティック回帰分析により多変量解析した。

[材料と方法]

平成 10 年 9 月より平成 13 年 3 月までに北海道大学医学部附属病院第 2 内科で教育入院し、歯 科保健指導を受けるため北海道大学歯学部附属病院保存系歯科を受診した糖尿病患者 57 名を被 験者とした。被験者の全歯について 6 点法の Pocket Probing を行った。また、オルソパントモグ ラフィーまたはデンタル 10 枚法にて X 線写真撮影を行い、歯槽骨吸収の程度を歯根長に対する 割合で各歯ごとに評価して、記録した。また被験者について内科より、診断名・糖尿病の罹患年 数・合併症の有無とその種類・HbAlc 值などの糖尿病デー夕を得た。さらに患者の性格や喫煙· 飲酒等の習慣、職業や同居家族の有無などの生活デー夕も教育入院時の記録より得た。生活状態 のデータ各項目のカテゴリーの違いにより、Probing Depth の平均值および歯槽骨吸収值の平均值 に差があるかどうか Mann-Whitney 検定を行った。歯周炎の罹患に影響を与える因子を検出する 目的でロジスティック回帰分析を行った。各患者の歯周炎の罹患を目的変数、糖尿病デー夕と生 活デー夕を説明変数とした。歯周炎罹患者は、 $5 \mathrm{~mm}$ 以上の Probing Depth と 50\%以上の歯槽骨吸 収值をそれぞれ 1 歯以上有するものとした。

[結果]

教育入院時の被験者の血糖コントロールレベルは良好な者からきわめて不良な者まで広範囲 にわたっていた。また歯周病についても軽度の歯肉炎から重度の歯周炎までその罹患程度は多様 であった。Mann-Whitney 検定の結果、飲酒習慣のある者、性格が短気である者は、Probing Depth の平均值が危険率 $5 \%$ で有意に高かった。歯槽骨吸収値について有意差を示した項目はなかった。 ロジスティック回帰分析で変数選択を行った結果、飲酒習慣と睡眠障害、HbAlc 值が歯周炎の罹 患に有意な $(\mathrm{p}<0.05)$ 影響を与える因子として検出された。これらの因子のオッズ比はそれぞれ 6.08(95\%CI:1.6〜22.93)、6.89(1.20～39.39)、3.98(1.03〜15.40)であった。

[考察]

本研究の結果は飲酒や睡眠障害が歯周病に直接的な影響を与えることを示しているものでは なく、糖尿病のコントロールレベルとともに、生活状態が歯周病罹患状態と関連している可能性 を示唆していると考えられる。本研究で検出した因子の背景に精神的ストレスなどの他の因子が 存在している可能性や、これらの因子が他の因子を介して影響している可能性などについて、今 後さらに多角的かつ詳細な検討を加える必要性が考えられた。 


\section{循環器疾患を有する患者の歯周組織状態}

\section{岩手医科大学歯学部歯科保存学第二講座}

○㐘池隆、熊谷敦史、鈴木健一、菅原教修、上野和之

Periodontal state of patients with cardiovascular disease

Department of Periodontology, School of Dentistry, Iwate Medical University

OTakashi Kikuchi, Atsushi Kumagai, Kenichi Suzuki, Michinobu Sugawara and Kazuyuki Uyeno

キーワード : 循環器疾患、歯周組織、疫学調查

【目的】

近年、歯周病が糖尿病、循睘器疾患、早産や低体重児出産などにリスク因子として関与しているという報告がなされている。 糖尿病患者の増加の割合や社会の少子高桻化を迎えるにあたり、歯周病と全身疾患との関連は看過できない重要な課題である と考えられる。細菌や免疫などの観点から疾病のメカニズムを検索するとともに歯周病と全身疾患の状態についての疫学的な 把握が重要であると考えられる。そこで、今回は循環器疾患で入院中に診療依頼があった集団を対象に、循環器疾患を有する 患者の口腔内状態、歯周組織状態の把握を行った。

【方法】

調查対象は岩手医科大学附属循睘器医療センターおよひ医学部第 2 内科 (循噮器) に入院しており、平成 12 年 1 月から平 成 13 年 6 月にセンターまたは第 2 内科からの依頼で歯学部第2 保存科を受診した 27 名（男性 21 名、女性 6 名）で、平均年 齢は64. 4 歳 (48歳 78歳、男性 64.3 歳、女性 67.8 歳) である。調査項目は、紹介目的、紹介時期、循環器疾患診断名、現 在歯数、初診時の口腔清掃状態 (0’ Lreary の Plaque control Record, PCR)、歯周ポケット染度、歯の動摇度、歯科疾患診 断名、治療内容、治療期間についてである。

\section{【結果】}

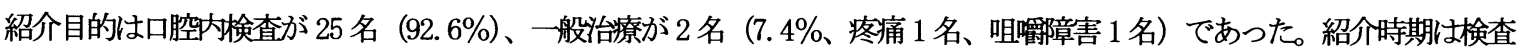
入院時が 2 名 $(7.4 \%) 、$ 手術前が 23 名 (85.2\%)、手術後が 2 名 (7.4\%) であった。循環器疾患診断名（重複）以高血圧が 17 名、腹部大動脈慮が 8 名、胸部大動脈瘤が 6 名、閉塞性動脈石更化症 3 名などがあり、循環器疾患診断名数が 1 診断名のもの が 4 名 $(14.8 \%) 、 2$ 診断名以上のものが 23 名 $(85.2 \%)$ であった。調査対象のうち糖尿病のものは 2 名であった。臨床検査 値より出血傾向が認められたものは 3 名 (11.1\%) であった。現在歯数の平均は 18.7 歯 (6歯〜29歯) であり、PCR の平均は $48.1 \%(8 \%$ \% $5 \%$ ) であった。歯周ポケットの平均は $3.8 \mathrm{~mm}$ ( $2 \mathrm{~mm} \sim 8 \mathrm{~mm})$ であり、 $4 \mathrm{~mm}$ 以上の部位を有する割合が $44.7 \%$ 、 $6 \mathrm{~mm}$ 以上の部位を有する割合が $18.7 \%$ であった。歯の動摇度が 2 末満の割合が $23.2 \%$ 、2以上の割合が $3.2 \%$ 科疾患の診断名（重複）では慢性辺縁性歯周炎が $96.3 \%$ 、根尖性歯周炎が $18.5 \%$ 、残根が $7.0 \%$ であった。感染源としてリス クが高いし判断したものは慢性辺稼性菌周炎で33.3\%、根尖性歯周炎で7.4\%であった。 全歯科疾患の治療内容 (重複)では 拔歯が $33.3 \%$ 、歯周治療が $74.1 \%$ 、根管治療が $22.2 \%$ であっ。歯周治療の内容 (重複) についてみると、啌清揥指導が $70.4 \% 、$ スケーリングが $70.4 \%$ であった。治療期間の平均は 4.4 週（1 週〜20 週）であった。

\section{【考察及び結論】}

歯周病関連細菌が細菌性心内膜炎などの全身疾患の発症や進行に関車することが指摘されている。循環器疾患を担当するセ クションからの紹介の多くは口腔内検查を目的としたもので、手術前の時期であった。年齢などを考慮すると、今回の調查対 象は現在歯数や口腔清掃状態、歯周組織の状態が著しく悪いものではなかったが、歯周組織破壊の高度な部位を含む例が多く みられた。治療内容についてみると、ほとんどの例で歯周治療が必要であると診断されていたが、手術前の紹介が多いため歯 周外科治療が行われた例はなかった。多くの要素を含む疾患間の相互関係を解明することは困難であるが、感染症という側面 と同時に、喫㖶などの生活習慣因子やストレスなどの外部環滰因子に関連する生活習慣病や代謝疾患として糖尿病や高血圧と ともに蒾周病を捉えるならば疾病間には関連が生じると考えられ、今後はより多くの対象を求めて病変の進行度との関車など について検索したいと考えている。 
歯周病と心藏血管疾患のリスクファクターとの関係について

長野県民 6200 人の調查より

長野県長野総合健康センター

○小出浩貴, 谷口崇拓, 北川原香, 笠原哲三, 青木伸之, 谷口威夫, 林花代彦

The Rerationship between Periodontal Disease and Risk Factor of

Cardiovascular Disease.

Nagano General Health Promotion Center

OHi roki Koide, Takahiro Taniguchi, Kaori ki tagawara, Tetuzou Kasahara,

Nobuyuki Aoki, Takeo Taniguchi, Kiyohiko Hayashi

キーワード : 心脿血管疾患, 全身疾患, 疫学調查

目的

近年とりわけ 1999 年以降海外で発表された $2 \sim 3$ の論文にもとづき、歯周病と虚血性心疾患 との関係が論議されてきているが日本における調查報告は殆どみられない。そこで今回当センター における一般臨床検查所見と比較し、類似の調査を行った。

対象および方法

当センターでは 25 年間にわたり年間 7000 余名の県民の全身健康診查を行っており中でも最 近 12 年間においては歯科健診を併せて行っている。両者の健診結果のデータにもとづき雪周病の 進行度と虚血性心疾患のリスクファクターとの関連を調查した。

H 1 2．4．１から H 13 3．3．３１の 1 年間に長野県長野総合健康センターを受診し歯科健診を 併せて行った有歯影者、男性 3982 名（63．5\%）、女性2285名（36．5\%）、計 62 67 名を対象とした。歯周病の進行度の指標としてC P I T N最大值・平均値およびパノラマX 線 所見における崡槽骨の吸収程度を、また、心炡血管疾患のリスクファクターとして 13 項目 (肥满、 空腹時血糖、グリコヘモグロビン、総コレステロール、HDLC、動脈硬化指数、トリグリセライ ド、心胸比、最高・最低血圧、体脂肪率、L D L C、C R P、心電図)にわたり調查を施行したが、 今回は C P I T N 平均値と心堿血管疾患のリスクファクターとの関係を中心に統計処理を行った。 また、虚血性心疾患の前駆症状としての心電図上の変化（S T 上昇等の異常）との比較も行った。 結果および考察

C P I T N平均值と前記心䐟血管疾患リスクファクターとの関連については歯周病の重症度に比 例してほぼ全てのリスクファクターにおいて異常値を示す割合が増加した。性別、年代別にみても 同様の結果が認められた。また、虚血性心疾患の前駆症状としての心電図の S T 上昇等の異常につ いても歯周病の進行度に比例して異常の発現率の増加を認めるという結果が得られた。

結論

本調查において歯周組織の炎症と心臓血管疾患のリスクファクターとの間に深い関連がある可能 性が示唆された。 


\section{鹿児岛県における成人歯科疾患実態調査 \\ -CPITN と臨床検査值および歯周病原性菌の血清抗体価との相関- 鹿児島大学歯学部歯科保存学講座 $(2)^{1}$ 予防歯科学講座 ${ }^{2}$}

$\bigcirc$ 下津 昭洋 ${ }^{1}$ 、古市 保志 ${ }^{1}$ 、伊藤 博夫 ${ }^{2}$ 、四元 幸治 ${ }^{1}$ 、井上 昌一 2 、和泉 雄一 ${ }^{1}$ Oral survey on adult residences in Kagoshima prefecture. Associations between CPITN, results of laboratorial test, and serum antibody titers of periodontpathic bacterium.

Department of Periodontology and Preventive Dentistry,Kagoshima University Dental School

Akihiro Shimotsu,Yasushi Furuichi,Hiro-O Ito,Yukihiro Yotsumoto, Masakazu Inoue,Yuichi Izumi キーワード : 歯周炎、臨床検査値、血清抗体価

【目的】

当教室では鹿児島県下で行われた歯科検診を含む成人基本健康診査時に得られた歯周疾患診査結果、全 身に関する検査結果の相関を比較検討し、本学会の第 43 回春季学術大会において報告した。本研究の 目的はさらに歯周病原性菌の血清抗体価を検査し、その結果について相関を比較検討するものであった。

【材料および方法】

出水市、曽於郡財部町、出水郡東町、大島郡徳之島町に在住し、基本健診を任意で受診した住民で歯科 検診を受けた被験者 1,314 名のデー夕を分析した。歯周組織の評価には CPITN を用いた。全身検査項 目として、体表指数 $(\mathrm{BMI}) 、$ 最高血圧(SBP)、最低血圧(DBP)、喫煙の有無、哭煙の量(pack/year)、専門 医師による心電図判定値 (1 50 5段階評価、ECG)、未梢血液検査としてアルカリフォスホターゼ値(ALP)、 総コレステロール值(T-CHO)、HDL-コレステロール值(HDL-CHO)、中性脂肪值(TG)、空腹時血糖値(FBG)、 白血球数(WBC)、血小板数(PLT)、C 反応性蛋白值(CRP)のデータが分析された。歯周病原性菌の血清抗 体価 (Porphyromonas gingivalis (P.g)の線毛、全菌体、Actinobacillus actinomycetemcomitans (A.a)の全菌体) は ELISA を用いて測定した。統計処理として、被験者のデ一夕は CPITN 最大值により異なる歯周組織 群（コード 0/1/2 群、コード 3 群、コード 4 群、コード MS 群）に分けられ ANOVA により群間におけ る有意差が検討され、またロジステック回帰分析によりオッズ比 (Odds Ratio)を求めた。

【結果】

1,314 名の CPITN コードの構成は、コード 0/1/2 群 ; 352 名、コード 3 群 ; 465 名、コード 4 群 ; 251 名、 コード MS 群 ; 246 名であり、年齢がコード 0/1/2 群とコード 3 群に有意差が認められ、コード MS 群と はすべての群において有意差が認められた。HDL-コレステロール值、白血球数、P.g 線毛、P.g 全菌体で コード $0 / 1 / 2$ 群とコード 4 群に有意差が認められ、白血球数、P.g 線毛、P.g 全菌体でコード 3 群と、コー ド 4 群に有意差が認められた。コード 4 群は男性を喫煙者に多かった。

コード MS 群を除いた 1,068 名でコード 4 群が存在するオッズ比は性別で男性が 2.03、喫煙で 1.73、最低 血圧で 1.27、白血球数で 1.24、C 反応性蛋白值で 2.39、P.g 線毛で 1.17、P.g 全菌体で $1.54 、 A . a$ 全菌体で 1.19 であった。

\section{【考察および結論】}

今回の結果より歯周組織の状態といくつかの臨床検査值および歯周病原性菌に対する血清抗体価に相関が 認められることが示された。またコード 4 群の $6 \mathrm{~mm}$ 以上のポケットを有する被験者群は全身状態、生活 習慣と相関があることが示唆された。今後さらに被験者数を増やし、血清抗体価、全身検査項目により歯 周疾患の状態の推察が可能かを検証していく予定である。

学部内協力者 ; 鉛山 ゆかり、日野 陽一、三重 幸恵（予防歯科学講座） 